\title{
STATUS GIZI DAN AKTIVITAS FISIK DENGAN STATUS HIDRASI PADA REMAJA DI SMA NEGERI 5 KOTA JAMBI
}

\author{
Merita, Aisah, Siti Aulia \\ Program Studi Ilmu Gizi, STIKES Baiturrahim Jambi
NUTRITIONAL STATUS AND PHYSICAL ACTIVITY WITH HYDRATION STATUS AMONG ADOLESCENT IN SENIOR HIGH SCHOOL, JAMBI CITY

\begin{abstract}
Indroduction: Hydration is a condition where healthy people maintain body water balance. It's around $46,1 \%$ of adolescent in Indonesia are mild dehydration. This study aims to determine the relationship between nutritional status and physical activity with hydration status in SMA Negeri 5, Jambi City.

Methods: This study used quantitative with cross sectional study. The sample of this study amounted to 90 respondents. Data analysis in this study consisted of univariate and bivariate (spearman correlation test).

Results: The results of this study showed that $56.7 \%$ of students are normal nutritional status, $47.8 \%$ of students do moderate physical activity, $57.8 \%$ of students are hydrated. Based on bivariate analysis, there was no significant correlation between physical activity and hydration status in adolescent ( $p$ value $=0,208)$. Conclusions: There is a significant relationship between nutritional status and hydration status and no relationship between physical activity and hydration status in adolescents. It is recommended to all students to monitor weight and do regular physical activity with drinking water consumption of at least 8 glasses per day.
\end{abstract}

Keywords: Adolescent, hydration, nutritional status, physical activity

\begin{abstract}
ABSTRAK
Latar Belakang: Hidrasi adalah kondisi dimana orang sehat yang menjaga keseimbangan air. Sekitar 46,1\% remaja di indonesia mengalami dehidrasi ringan. Penelitian ini bertujuan untuk mengetahui hubungan status gizi dan aktivitas fisik dengan status hidrasi di SMA Negeri 5 Kota Jambi.

Metode: Jenis penelitian ini adalah kuantitatif dengan desain studi cross sectional. Sampel penelitian ini berjumlah 90 responden. Analisis data dalam penelitian ini terdiri dari univariat dan bivariat (spearman correlation test).

Hasil: Hasil penelitian ini menunjukkan bahwa 56,7\% siswa berstatus gizi normal, 47,8\% siswa melakukan aktivitas fisik sedang, 57,8\% siswa terhidrasi. Berdasarkan analisis bivariat diketahui terdapat hubungan yang signifikan antara status gizi dengan status hidrasi pada remaja ( $\mathrm{p}$ value $=0,026$ ), tidak terdapat hubungan yang signifikan antara aktivitas fisik dengan status hidrasi pada remaja (p value $=0,208$ ).

Kesimpulan:Terdapat hubungan yang signifikan antara status gizi dengan status hidrasi dan tidak terdapat hubungan antara aktivitas fisik dengan status hidrasi pada remaja. Disarankan kepada semua siswa untuk memantau berat badan dan melakukan aktivitas fisik secara rutin disertai konsumsi air minum minimal 8 gelas per hari.
\end{abstract}

Kata Kunci : Aktivitas fisik, hidrasi, remaja, status gizi 


\section{PENDAHULUAN}

Air merupakan komponen terbesar dalam tubuh dan separuh dari tubuh kita terdiri dari air. Tubuh manusia rata-rata tersusun atas 63\% air, 17\% lemak, 6\% mineral, $1 \%$ karbohidrat dan vitamin. Seseorang kehilangan $40 \%$ lemak dan protein dapat terjadi penurunan berat badan tetapi masih mampu bertahan hidup, akan tetapi kehilangan $20 \%$ air dapat menyebabkan kematian. $^{1}$

Menurut World Health Organization (WHO), kebutuhan air untuk usia 14-18 tahun, laki-laki 3,3 L/hari dan perempuan 2,3 L/hari. ${ }^{2}$ Sementara itu, berdasarkan Angka Kecukupan Gizi tahun 2013 diketahui bahwa kebutuhan air bagi remaja laki-laki usia 1418 tahun adalah 2000-2200 ml sedangkan bagi perempuan 2000-2100 ml. Jika jumlah air yang kita konsumsi tidak terpenuhi dapat menyebabkan terjadinya dehidrasi. ${ }^{3}$

Dehidrasi adalah ketika tubuh kehilangan cairan tubuh dalam jumlah besar dan dapat menyebabkan rasa haus, hilangnya nafsu makan, menurunnya urinasi, pusing, lemah, sakit otot, meningkatnya denyut nadi dan respirasi, gangguan penampakan fisik dan pengaturan temperatur. ${ }^{4}$ Banyak orang mengasumsikan bahwa haus merupakan indikator saat tubuh membutuhkan air, haus merupakan regulator utama asupan cairan. Haus timbul akibat adanya kehilangan cairan, bahkan dalam jumlah sedikit. $^{5}$

Remaja adalah individu baik perempuan maupun laki-laki yang berada pada masa antara anak-anak dan dewasa. Penelitian di Brazil menunjukan bahwa sebesar $22 \%$ pada remaja ternyata masih mengkonsumsi air di bawah jumlah yang cukup. ${ }^{6}$ Penelitian di Indonesia yang dilakukan pada remaja SMA di Bogor mendapatkan hasil sebesar $37,3 \%$ remaja yang minum kurang dari 8 gelas per hari. ${ }^{7}$ Hasil penelitian THIRST (The Indonesian Regional Hydration Study) tahun 2009 menunjukan bahwa $46,1 \%$ subyek remaja dan dewasa mengalami dehidarasi ringan, yang setara dengan kekurangan air tubuh sekitar $2 \%{ }^{8}$

Beberapa faktor yang dapat mempengaruhi terjadinya dehidrasi seperti, jenis kelamin, usia, status gizi, aktivitas fisik, suhu tubuh, dan suhu lingkungan. Pada status gizi obesitas air tubuh total lebih rendah dibandingkan dengan orang yang tidak obesitas, kandungan air di dalam sel lemak lebih rendah dari pada kandungan air di dalam sel otot sehingga orang obesitas lebih mudah kekurangan air dibandingkan dengan orang yang tidak obesitas. ${ }^{9}$

Hasil data Riset Kesehatan Dasar (Riskesdas) tahun 2013 diketahui prevalensi status gizi (IMT/U) usia 16-18 tahun untuk kejadian status gizi kurus di Indonesia sebesar 9,4\%, status gizi gemuk sebesar $7,3 \%$ yang terdiri dari $5,7 \%$ gemuk dan $1,6 \%$ obesitas. ${ }^{9}$ Sementara itu, data Riskesdas Provinsi Jambi (2013) menunjukkan prevelensi status gizi (IMT/U) usia 16-18 tahun untuk kejadian gemuk di Kota Jambi sebesar $21 \%$, untuk status gizi normal sebesar $88,4 \%$, status gizi kurus sebesar $7,4 \%$, dan status gizi sangat kurus sebesar $2,1 \% .{ }^{10}$ Hasil penelitian Buanasita et al menyatakan bahwa mahasiswa yang obesitas mengalami dehidrasi lebih tinggi sebesar 77,8\% sedangkan yang non obesitas $22,2 \%$, ini menunjukan bahwa status gizi dapat mempengaruhi status hidrasi mahasiswa di Akademik Gizi Surabaya. ${ }^{11}$

Berdasarkan data Riskesdas tahun 2013 mengenai aktivitas fisik diketahui bahwa penduduk umur $\geq 10$ tahun di Indonesia 73,9\% tergolong aktif dan 26,1\% kurang aktif, sedangkan di Jambi 68,8\% tergolong aktif dan $31,2 \%$ kurang aktif. ${ }^{10}$ Penelitian Utami dan Widyastuti mengenai status hidrasi setelah tes ketahanan fisik mahasiswa di Universitas Negeri Semarang, jurusan tari usia 19 - 22 tahun mendapatkan hasil pengukuran status hidrasi menunjukan bahwa 43,4\% mengalami dehidrasi yang 
signifikan dan sisanya sebesar $56,6 \%$ mengalami dehidrasi. ${ }^{12}$

Aktivitas fisik umumnya diartikan sebagai gerak tubuh yang ditimbulkan oleh otot-otot skeletal dan mengakibatkan pengeluaran energi. Dehidrasi memiliki dampak negatif pada kinerja fisik untuk kegiatan yang berlangsung lebih dari 30 detik, namun dehidrasi tidak memiliki dampak yang signifikan pada kinerja fisik untuk kegiatan yang berlangsung kurang dari 15 detik. ${ }^{13}$

Peneliti memilih populasi remaja sekolah tingkat SMA. Lokasi yang digunakan dalam penelitian ini adalah SMA Negeri 5 Kota Jambi dengan jumlah siswa pada tahun 2015 sebesar 1749 orang. Berdasarkan survei awal jumlah siswa SMA Negeri 5 Kota Jambi pada tahun 2016 adalah 1.901 siswa, 882 siswa laki-laki dan 1019 siswa perempuan. Hasil survei awal yang dilakukan pada 10 siswa, didapatkan 7 siswa berstatus gizi normal dan 3 siswa berstatus gizi obesitas. Status hidrasi didapatkan 7 siswa terhidrasi dengan baik, 1 siswa dehidrasi ringan dan 2 siswa mengalami dehidrasi berat. Tingkat aktivitas fisik yang didapatkan adalah 3 siswa tergolong aktivitas tinggi, 4 siswa tergolong aktivitas sedang, dan 3 siswa lainnya tergolong aktivitas ringan. Berdasarkan permasalahan tersebut, tujuan dari penelitian ini adalah untuk mengetahui hubungan status gizi dan aktivitas fisik dengan status hidrasi di SMA Negeri 5 Kota Jambi.

\section{METODE}

Penelitian ini merupakan penelitian kuantitatif dengan desain cross sectional study. Penelitian ini dilaksanakan di SMA Negeri 5 Kota Jambi pada Maret s/d Juli 2017. Jumlah populasi pada penelitian ini 1.267 siswa. Berdasarkan perhitungan sampel menggunakan rumus Lameshow maka diperoleh jumlah sampel sebesar 90 siswa. Teknik pengambilan sampel yang digunakan adalah proportional random sampling.
Instrumen yang digunakan pada penelitian ini terdiri dari kuesioner dan alat pengukuran status gizi serta status hidrasi. Status gizi diukur dengan menimbang berat badan menggunakan timbangan berat badan electric dan mengukur tinggi badan dengan menggunakan microtoise. Data aktivitas fisik diperoleh dengan wawancara menggunakan kuesioner standar WHO tahun 2010 yaitu Global Physical Activity Questionnaire (GPAQ). Sementara itu, untuk mengukur status hidrasi digunakan teknik pengukuran warna urine untuk mengetahui status hidrasi responden, urin diambil pada jam 09.0011.00 pada saat siswa berada disekolah. Alat yang digunakan sebagai alat ukur status hidrasi pada penelitian ini adalah kartu PURI (Periksa Urin Sendiri), kemudian warna urin dibandingkan dengan Kartu PURI. Pada penelitian ini pengukuran status gizi, status hidrasi serta wawancara aktivitas fisik dilakukan oleh peneliti dan dibantu dengan petugas lapangan. Data yang dikumpulkan dianalisis secara univariat dan bivariat (spearman).

\section{HASIL \\ Karakteristik Responden}

Hasil penelitian menunjukkan bahwa sebagian besar responden berjenis kelamin laki-laki (53,3\%). Rentang usia responden dalam penelitian ini adalah remaja menegah (15-17 tahun) yaitu seanyak 91,1\% responden.

\section{Gambaran Status Gizi, Aktivitas Fisik, dan Status Hidrasi}

Distribusi frekuensi subjek penelitian berdasarkan status gizi, aktivitas fisik, dan status hidrasi dapat dilihat pada Tabel 1 di bawah ini. 
Tabel 1.

Distribusi Frekuensi Responden Berdasarkan Status Gizi Pada Remaja di SMA Negeri 5 Kota Jambi

\begin{tabular}{|c|c|c|}
\hline Variabel & Frekuensi (n) & Persentase (\%) \\
\hline \multicolumn{3}{|l|}{ Status Gizi } \\
\hline Normal & 51 & 56,7 \\
\hline Gemuk & 24 & 26,7 \\
\hline Obesitas & 15 & 16,7 \\
\hline \multicolumn{3}{|l|}{ Aktivitas Fisik } \\
\hline Sedang & 43 & 47,8 \\
\hline Berat & 29 & 32,2 \\
\hline \multicolumn{3}{|l|}{ Status Hidrasi } \\
\hline Hidrasi baik & 52 & 57,8 \\
\hline Dehidrasi Ringan & 38 & 42,2 \\
\hline
\end{tabular}

Berdasarkan Tabel 1. di atas dapat diketahui bahwa sebagian besar responden memiliki status gizi normal (56,7\%). Akan tetapi, masih ditemukan mengalami kegemukan $(26,7 \%)$ dan obesitas $(16,7 \%)$. Sebagian besar responden melakukan aktivitas fisik sedang. Diketahui pula responden yang mengalami dehidrasi ringan lebih sedikit dibandingkan responden yang terhidrasi dengan baik.

\section{Hubungan status gizi dengan status hidrasi pada remaja}

Berdasarkan hasil analisis korelasi spearman diketahui terdapat hubungan yang signifikan antara status gizi dengan status hidrasi pada remaja di SMA N 5 Kota Jambi degan nilai $\mathrm{p}$ value $=0,026$ dan dari hasil analisis diperoleh juga nilai $r=0,235$, hal ini menunjukan terdapatnya hubungan yang lemah dan positif antara status gizi dengan status hidrasi, dapat diartikan bahwa semakin gemuk seseorang maka semakin tinggi pula peluang untuk mengalami dehidrasi.

\section{Hubungan aktivitas fisik dengan status hidrasi pada remaja}

Berdasarkan hasil analisis korelasi spearman diketahui tidak terdapat hubungan yang signifikan antara aktivitas fisik dengan status hidrasi pada remaja di SMA N 5 Kota Jambi, dengan nilai $\mathrm{p}$ value $=0,208$ dan dari hasil analisis diperoleh juga nilai $r=0,134$, hal ini menunjukan terdapatnya hubungan yang lemah dan positif antara aktivitas fisik dengan status hidrasi, dapat diartikan bahwa semakin tinggi aktivitas yang dilakukan maka semakin tinggi peluang untuk mengalami ddehidrasi.

\section{PEMBAHASAN}

\section{Gambaran Status Gizi}

Status gizi dibedakan menjadi lima yaitu sangat kurus, kurus, normal, gemuk, dan obesitas. ${ }^{13}$ Berdasarkan Keputusan Menteri Kesehatan Republik Indonesia No.1995/Menkes/SK/XII/2010 diketahui bahwa penilaian status gizi remaja didasarkan pada Indeks IMT/U. ${ }^{14}$ IMT (Indeks massa tubuh) adalah hasil dari pembagian dari berat badan dengan tinggi badan yang dikuardatkan.

Berdasarkan hasil penelitian diketahui bahwa sebagian besar responden memiliki status gizi normal $(56,7 \%)$, tetapi terdapat $26,7 \%$ respoden mengalami kegemukan dan $16,7 \%$ responden mengalami obesitas. Adanya responden yang mengalami kegemukan dan obesitas diduga karena tinggi asupan energi dan gemar mengkonsumsi fast food tetapi tidak diimbangi dengan aktivitas 
fisik yang cukup sehingga menyebabkan terjadinya obesitas. Hasil penelitian ini sejalan dengan penelitian yang dilakukan oleh Ruslie dan Darmadi menyatakan bahwa $9,03 \%$ remaja mengalami underweight, $70,83 \%$ remaja memiliki status gizi normal dan 20,14\% remaja mengalami overweight. Demikian pula hasil penelitian Fajri dkk yang menunjukkan bahwa sebagian besar remaja di SMA N 17 dan SMA Nurul Iman Palembang memiliki status gizi baik $(61,7 \%) .^{15}$

\section{Gambaran Aktivitas Fisik}

Aktivitas fisik umumnya diartikan sebagai gerak tubuh yang ditimbulkan oleh otot-otot skeletal dan mengakibatkan pengeluaran energi. Ketika menilai aktivitas fisik, paling tidak terdapat empat dimensi utama yang menjadi fokus, yaitu tipe, frekuensi, durasi, dan intesitas aktivitas fisik. ${ }^{15}$ Aktivitas fisik dibedakan menjadi 3 yaitu ringan, sedang dan berat. ${ }^{16}$ Metode pengkajian subjektif meliputi, catatan harian aktivitas, kuesioner aktivitas fisik. ${ }^{16}$

Pada penelitian ini metode yang digunakan adalah Global Physical Activity Questionnaire (GPAQ) yang dibagikan kepada responden. Berdasarkan hasil penelitian yang dilakukan diketahui bahwa sebanyak 47,8\% responden melakukan aktivitas fisik sedang, $20 \%$ responden melakukan aktivitas ringan, dan terdapat $32,2 \%$ responden melakukan aktivitas berat.

\section{Gambaran Status Hidrasi}

Menurut The European Food Safety Authority (EFSA) tahun 2010 menyatakan bahwa status hidrasi adalah kondisi dimana orang sehat yang menjaga keseimbangan air, perubahan yang kecil sulit untuk diukur karena tubuh terus-menerus berusaha memelihara volume plasma dan menjaga homeostasis. ${ }^{17}$ Menurut Feltz el al., jika seseorang terhidrasi dengan baik maka warna urin akan semakin jernih dan transparan. ${ }^{18}$
Warna urin memungkinkan orang untuk menilai status hidrasi mereka sendiri, idealnya urine berwarna kuning pucat sesuai dengan keadaan hidrasi optimal. ${ }^{19}$ Berdasarkan penelitian ini diketahui bahwa sebagian besar siswa terhidrasi dengan baik $(55,9 \%)$, namun masih ditemukan 41 responden (44\%) mengalami dehidrasi ringan. Sebelum dilakukan pengambilan urin peneliti melakukan recall 1 x 24 jam mengenai minuman yang dikonsumsi responden dan ketahui bahwa sebagian bessar responden mengkonsumsi air putih, namun terdapat beberapa responden mengkonsumsi teh manis dan jus jeruk, dan susu.

The Indonesian Regional Hydration Study (THIRST) 2010, dehidrasi jangka pendek atau dehidrasi ringan terjadi pada kelompok usia remaja (15-18 tahun) sebesar 49,5\%. ${ }^{8}$ Penelitian di Jerman, menemukan bahwa sebanyak $22 \%$ anak sekolah mengalami hidrasi ringan. Ada beberapa tanda-tanda dehidrasi yang dapat dirasakan seperti menimbulkan haus, lelah, lemah, tidak nyaman, kehilangan nafsu makan, mulut kering, kulit kering, penurunan jumlah urin, apatis, kehilangan konsentrasi, dan penurunan kemampuan fisik, sakit kepala, mudah mengantuk. ${ }^{20}$

\section{Hubungan Status Gizi dengan Status Hidrasi pada Remaja}

Berdasarkan hasil analisis kolerasi Spearman yang dilakukan diketahui bahwa adanya hubungan yang signifikan antara status gizi dengan status hidrasi dengn nilai $\mathrm{p}$ value $=0,026$ dan nilai $\mathrm{r}=0,235$. Hal ini dapat diartikan bahwa semakin gemuk maka semakin tinggi pula risiko orang tersebut mengalami dehidrasi.

Hasil penelitian ini sejalan dengan penelitian lainnya yang menyimpulkan bahwa kejadian dehidrasi lebih banyak dialami remaja obesitas dibanding non obesitas dengan $\mathrm{p}=0,024 .^{21}$ Penelitian yang dilakukan oleh Buanasita et al yang 
menyatakan bahwa sebagian besar mahasiswa obesitas mengalami dehidrasi lebih tinggi sebesar 77,8\% sedangkan yang non obesitas $22,2 \%$, ini menunjukan bahwa status gizi dapat mempengaruhi status hidrasi. Penelitian yang dilakukan Pertiwi menyatakan bahwa adanya hubungan antara siswa yang obesitas dengan status dehidrasi jangka pendek sebesar $83,3 \% .^{11}$

Pada penelitian ini, ditemukan bahwa kejadian dehidrasi lebih banyak dialami siswa berstatus gizi tidak normal $(63,1 \%)$ yang terdiri dari status gizi gemuk $(36,8 \%)$ dan obesitas (26,3\%), jika dibandingkan dengan siswa yang status gizi normal $(36,8 \%)$. Dengan demikian, seseorang yang gemuk dan obesitas lebih cendrung mengalami dehidrasi.

Salah satu faktor resiko terjadinya dehidrasi adalah kelebihan berat badan (overweight). Hal ini disebabkan karena terjadi ketidakseimbangan elektrolit dalam tubuh dan menekan seseorang meningkatkan nafsu makan serta asupan makannya sehingga akan menurunkan asupan cairan dalam tubuh. ${ }^{22}$ Pada obesitas, air tubuh total lebih rendah dibandingkan dengan orang yang tidak obesitas, kandungan air di dalam sel lemak lebih rendah daripada kandungan air di dalam sel otot sehingga orang obesitas lebih mudah kekurangan air dibandingkan dengan orang yang tidak obesitas. ${ }^{9}$

Jumlah air diluar sel berbeda menurut tingkat kegemukan seseorang, orang gemuk memiliki jumlah air yang lebih rendah dibandingkan pada orang kurus. Jumlah air di luar sel pada orang kurus kurang lebih 25\% berat badan, pada orang orang memiliki berat badan sedang $20 \%$ berat badan, dan pada orang gemuk hanya $15 \%$ berat badan. ${ }^{23}$ Pada penderita kegemukan dan obesitas sinyal lapar dan haus sulit untuk dibedakan, orang obesitas lebih terbiasa menanggapi sinyal lapar bila dibandingkan dengan sinyal haus. Kedua sinyal ini termasuk respon subyektif dan dikeluarkan oleh sumber yang sama yaitu histamin. Makanan dianggap memberikan efek yang lebih besar sebagai sensasi rasa kenyang bila dibandingkan dengan minum air. ${ }^{1}$ Hasil penelitian yang dilakukan oleh Tammy et al., menyatakan bahwa adanya hubungan yang signifikan hidrasi yang tidak adekuat dengan kejadian obesitas. ${ }^{24}$

Oleh karena itu diharapkan pada siswa yang memiliki status gizi kegemukan dan obesitas agar melakukan penurunan berat badan sehingga dapat mencapai berat badan normal. Kebutuhan air untuk mempertahankan status hidrasi rata-rata memerlukan 2-3 Liter per hari atau sekitar 810 gelas sehari. Sementara itu, diharapkan siswa rutin memantau berat badan karena semakin gemuk seseorang maka semakin tinggi pula risiko terjadinya dehidrasi.

\section{Hubungan Aktivitas Fisik dengan Status Hidrasi pada Remaja}

Hasil analisis uji kolerasi spearman hubungan antara aktivitas fisik dengan status hidrasi menunjukkan sebanyak 19 responden $(18,2 \%)$ dengan aktivitas fisik sedang mengalami dehidrasi, 14 responden $(12,2 \%)$ dengan aktivitas berat mengalami dehidrasi dan 5 responden $(7,9 \%)$ dengan aktivitas fisik ringan mengalami dehidrasi. Berdasarkan analisis kolerasi spearman menunjukkan bahwa tidak terdapat hubungan yang signifikan antara aktivitas fisik dengan status hidrasi dengan nilai $\mathrm{p}$ value $=0,208$ dan nilai $r=0,134$.

Hasil penelitian ini sejalan dengan penelitian yang dilakukan oleh Pertiwi menyatakan tidak terdapat hubungan yang signifikan antara aktivitas fisik dengan status dehidrasi jangka pendek dengan nilai $\mathrm{p}$ value 0,594 . Penelitian menggunakan data skala nasional menunjukkan bahwa terdapat hubungan anatara status dehidrasi dengan tingkat aktivitas fisik dengan nilai $\mathrm{p}$ value sebesar $0,918 .^{25}$

Pada penelitian ini, diketahui bahwa yang paling banyak mengalami dehidrasi adalah siswa yang melakukan aktivitas 
sedang yaitu sebesar $18,2 \%$, sedangkan siswa yang melakukan aktivitas fisik berat yang mengalami dehidrasi sebesar $12,2 \%$. Hasil dalam penelitian ini menunjukkan bahwa tidak ada hubungan yang signifikan antara aktivitas fisik dengan status hidrasi, hal ini diduga karena sebagian besar siswa melakukan aktivitas sedang dan diduga responden menkonsumsi air minum yang cukup sebelum dilakukan penelitian. Namun, baik aktivitas tinggi maupun rendah, keduanya memiliki peluang terhadap dehidrasi. Aktivitas fisik yang rendah juga dapat menyebabkan berkurangnya konsumsi minum sehingga terdapat peluang untuk terjadinya dehidrasi. ${ }^{7}$

Aktivitas fisik memiliki hubungan dengan asupan air, remaja lebih sering mengalami dehidrasi dikarenakan banyaknya aktivitas fisik remaja yang dapat menguras tenaga dan cairan tubuh, sehingga menyebabkan kurangnya konsumsi cairan. ${ }^{7}$ Pengaturan air manusia bergantung pada sensasi hausnya, kika tidak merasa haus maka manusia cenderung tidak minum air. ${ }^{1}$ Meskipun dalam penelitian ini tidak terdapat hubungan yang signifikan tetapi terdapat korelasi yang lemah antara aktivitas fisik dengan status hidrasi dapat diartikan bahwa semakin tinggi aktivitas seseorang maka semakin tinggi risiko terjadinya dehidrasi.

Kebutuhan cairan berbanding lurus dengan aktivitas fisik, semakin berat aktivitas yang dikerjakan, maka semakin banyak pula kebutuhan cairnnya karena cairan tersebut akan memicu rasa haus yang mendorong seseorang untuk minum. Selama aktivitas ringan di lingkungan yang dingin atau sedang, tingkat berkeringat hanya mencapai $100 \mathrm{~mL} / \mathrm{jam}$, namun selama aktivitas berat di lingkungan panas, beberapa individu dapat berkeringat mencapai lebih dari 3.000 $\mathrm{mL} / \mathrm{jam} .{ }^{26}$ Tingkat berkeringat tinggi (misalnya 1,5 L/jam) dapat menyebabkan kondisi dehidrasi yang signifikan dan cenderung mengalami gangguan kerja. ${ }^{27}$ Penelitian mengenai status hidrasi setelah tes ketahanan fisik mahasiswa jurusan tari usia 19 - 22 tahun mendapatkan hasil pengukuran status hidrasi menunjukan bahwa 43,4\% mengalami dehidrasi berat dan sisanya sebesar 56,6\% mengalami dehidrasi ringan. ${ }^{12}$

Meskipun tidak ada hubungan status hidrasi dengan aktivitas fisik, namun tetap disarankan bagi siswa untuk tetap mengkonsumsi air minum sesuai dengan yang dianjurkan yaitu 8 gelas per hari karena semakin tinggi aktivitas fisik yang dilakukan maka semakin tinggi pula risiko terjadinya dehidrasi. Sementara itu, aktifitas fisik yang teratur, banyak gerak dan rajin berolahraga terutama olahraga juga bermanfaat untuk meningkatkan kepadatan tulang, seperti senam beban penting untuk perkembangan dan menjaga tulang yang kuat. ${ }^{28}$

Penelitian ini memiliki beberapa kekurangan akibat keterbatasan dari peneliti adalah faktor-faktor yang mempengaruhi status hidrasi terdiri dari status gizi, aktivitas fisik, usia, jenis kelamin, total asupan cairan, suhu tubuh, suhu lingkungan, sedangkan peneliti hanya meneliti dua faktor yaitu status gizi dan aktivitas fisik.

Total pengeluran air tidak dihitung karena sulit dihitung karena terdapat beberapa sumber pengeluaran air seperti feses, keringat (kulit), pernapasan (paru-paru) dan memerlukan biaya lebih serta pengawasan saat pengambilan data. Total asupan cairan tidak dihitung karena adanya keterbatasan waktu yang dimiliki peneliti serta adanya keterbatasan penelitian dengan menggunkan kuesioner yaitu terkadang jawaban yang diberikan oleh sampel tidak menunjukkan keadaan sesungguhnya.

\section{KESIMPULAN DAN SARAN}

Berdasarkan hasil penelitian dapat disimpulkan bahwa sebagian besar remaja di SMA N 5 Kota Jambi berstatus gizi normal, melakukan aktivitas fisik sedang, dan terhidrasi dengan baik. Analisis korelasi spearman menunjukkan bahwa terdapat hubungan signifikan antara status gizi dengan status hidrasi $(\mathrm{p}=$ value 0,$026 ; \mathrm{r}=0,235)$. 
Namun, tidak terdapat hubungan antara aktivitas fisik dengan status ( $\mathrm{p}=$ value 0,$208 ; \mathrm{r}$ $=0,134$ ).

Berdasarkan hasil penelitian ini, penulis merekomendasikan pihak sekolah untuk menyediakan sarana dan prasarana tempat air minum disekolah. Perlu juga ditambahkan materi mengenai dehidrasi di salah satu mata pelajaran seperti di mata pelajaran penjaskes, guna menambah pengetahuan siswa mengenai dehidrasi, serta sekolah disarankan melengkapi fasilitas di UKS yang berguna untuk memantau berat badan siswa. Sementara itu, bagi remaja diharapkan rutin memantau berat badan, dan dapat menurunkan berat badan untuk mencapai berat badan normal bagi remaja kegemukan dan obesitas. Diharapkan pula bagi remaja agar rutin melakukan aktivitas

\section{DAFTAR PUSTAKA}

1. Batmanghelidj F. Air untuk menjaga kesehatan dan menyembuhkan penyakit. Jakarta: Gramedia Pustaka Utama; 2007

2. World Health Organization. Nutrients in drinking water. Geneva; 2005

3. Kemenkes RI. Angka Kecukupan Gizi Yang Dianjurkan bagi Bangsa Indonesia. Jakarta: Kemenkes RI; 2013

4. Devi N. Nutrition and food gizi untuk keluarga. Jakarta : PT.Kompas Media Nusantara; 2010

5. Brenna H, Libby T, Susan W. Nutrition made incredibly easy. Edisi 2. Nugroho W Aryandhito, Niko S, Penerjemah. (2013). Ilmu Gizi Menjadi Sangat Mudah. Jakarta : EGC; 2008

6. Sousa de E, Costa Da T, Nogueira D J, Vivaldi J L. Assessment of nutrient and water intake among adolescents from sports federations in the Federal District, Brazil. British Journal of Nutrition. 2007; 99: 1275-1283

7. Briawan, dkk. Kebiasaan minum dan asupan cairan di perkotaan. Jurnal Klinik Gizi Indonesia. 2011; 8(1): 3641 fisik dan diimbangi dengan konsumsi air minum yang cukup minimal 8 gelas per hari.

Bagi peneliti selanjutnya, diharapkan bagi peneliti selanjutnya dapat melakukan penelitian yang sejenis dengan metode dan variabel yang berbeda dan memperhatikan faktor yang sangat berpengaruhi yaitu asupan cairan.

\section{UCAPAN TERIMAKASIH}

Penulis mengucapkan terimakasih kepada STIKES Baiturrahim Jambi yang telah memberikan bantuan dana penelitian sehingga penelitian ini dapat terlaksana dengan baik. Selain itu, ucapan terimakasih juga disampaikan kepada pihak sekolah SMA N 5 Kota Jambi, responden, dan enumerator yang sudah berkontribusi dalam pelaksanaan penelitian.

8. Santoso BI, Hardinsyah, Siregar P, Pardede SO. Air Bagi Kesehatan. Jakarta: Centra Communications; 2011

9. Kemenkes RI. Riset Kesehatan Dasar (Riskesdas) Nasional tahun 2013. Jakarta: Kementrian Kesehatan Republik Indonesia; 2013

10. Riset Kesehatan Dasar Provinsi Jambi. Pokok-Pokok Hasil Riset Kesehatan Dasar Provinsi Jambi; 2013

11. Utami A, Widyastuti N. Status Hidrasi Setelah Tes Ketahanan Fisik Mahasiswa Jurusan Tari Usia 19 - 22 Tahun (Studi Kasus Di Universitas Negeri Semarang). Journal of Nutrition College, 2015; 4(2): 25-32

12. Carlton A, Marc O R. 2015. The effects of fluid loss on physical performance: A critical review. Journal of Sport and Health Science. 2015; 2(4): 357-363

13. World Health Organization. Growth reference 5-19 years. Geneva; 2007

14. Kempenkes. Keputusan Menteri Kesehatan Republik Indonesia No.1995/Menkes/SK/XII/2010.

Jakarta; 2011

15. Hartono A, Widyastuti P, Hardiyanti E, Penerjemah. Gizi Kesehatan Masyarakat. Jakarta : Buku Kedokteran EGC; 2009 
16. World Health Organization. Global Physical Activity Questionnaire (GPAQ). Geneva; 2010

17. European Food Safety Authority (EFSA). Scientific Opinion on Dietary Reference Values for water. EFSA Journal. 2010; 8(3):1459

18. Feltz, Brian D, Ferra, Joe. Dehydration's hidden symptoms. Chiropratic Journal. 2006; 20 (10): 1-2

19. Armstrong E Lawrence. Hydration Assessment Techniques. International Life Sciences Institute. 2005; 63(6): S40-S54

20. Hardinsyah, Briawan, Hartati A, Thaha. THIRST. Pergizi Pangan Indonesia, FEMA IPB, FKM UNAIR, dan FKM UNHAS; 2010

21. Puspaningtyas D, Prasetyaningrum Y. Variasi Favorit Infused Water Berkhasiat. Jakarta : F Media; 2014

22. Prayitno, S.O, Fillah Dieny. F. Perbedaan Konsumsi Cairan Dan Status Hidrasi Pada Remaja obesitas Dan Non Obesitas. Journal Of Nutrition College, 2012; 1(1): 32-48

23. Buanasita A, Andriyanto, Sulistyowati I. Perbedaan Tingkat Konsumsi Energi, Lemak, Cairan, dan Status Hidrasi Mahasiswa Obesitas dan Non Obesitas. Indonesian Journal of Human Nutrition, 2015; 2(1) : $11-22$.

24. Fauziyah, M. Sehat Dengan Air Putih. Stomata. Surabaya; 2011

25. Almatsier S, Susirah S, Moesijanti S. Gizi seimbang dalam daur kehidupan. Jakarta: Penerbit PT Gramedia Pustaka Utama; 2011

26. Tammy C, Nithin R, Melissa A, Kendrin R, Matthew M. D. Inadequate Hydration, BMI, and Obesity Among US Adults: NHANES 2009-2012. Annals Of Family Medicine. 2016; 14(4): $13-25$

27. Hardinsyah, Gustam, Briawan. Faktor risiko dehidrasi pada remaja dan dewasa Indonesia. Jurnal Gizi dan Pangan. 2012; 2(2): 23-37

28. Berning $\mathbf{J}$ et al. Perspective in nutrition. New York : McGrave-Hill; 2007

29. Murray B. Hydration and physical performance. Journal of the American College of Nutrition. 2007; 26(5):542S-548S 